\title{
A.T. Tvardovsky in Creative Consciousness of V.P. Astafiev
}

\author{
Victor V. Il'in and Oksana A. Novikova* \\ Smolensk State University \\ 4 Przhevalskogo Str., Smolensk, 214000, Russia
}

Received 19.12.2015, received in revised form 30.01.2016, accepted 18.03.2016

The article observes the attitude of $V$. Astafiev towards personality and works of A. Tvardovsky. Memorial notes of Astafiev demonstrate his respect towards Tvardovsky-poet and Tvardovsky-chief editor of Novy Mir journal. A comparative analysis of works of two famous Russian traditionalist writers reveals certain typological analogies, literature connections and impacts. Writers' works, research papers on the subject of the study, literary critical opinions as well as previously unpublished biographical facts of Astafiev, connected with his trip to Smolensk Region (1985) and testimonies of Tvardovsky's daughter were used while writing this article. The presence of parallels and possible borrowings in the system of characters and motives of writers is established.

Keywords: V. Astafiev, A. Tvardovsky, traditionalist writers, comparativistics, work psychology, literary tradition, Novy Mir journal.

DOI: 10.17516/1997-1370-2016-9-5-1140-1147.

Research area: philology.

The problem of literary connections revelation plays the crucial role in defining the artistic talent dominant of a writer. In this case a comparative-typological method turns out to be the most functional, since an approach of comparisons, search of similarities, resemblances together with a strict control of differences, distinctions, dilogies is a direct way to the truth.

In the introductory article of "Russian writers of the $20^{\text {th }}$ century. Biographical dictionary" publication, its chief editor P.A. Nikolaev speaking about "village prose" as "the main artistic achievement" of the second half of the $20^{\text {th }}$ century, stated that this achievement "was prepared by the great poetic experience of A.
Tvardovsky" [Russkie pisateli (2000), p. 5]. Though, such an impact should be proved by examining the largest possible circle of writers, who are now called the writers of "folk mode" "traditionalists", "nationalists". Victor Astafiev certainly belongs to them [Kovtun (2009)].

In the history of Russian literature, A.Tvardovsky and V. Astafiev represented remarkable phenomena of artistic culture, though they were people from different generations: they were separated by an important 14-years period in the development of our country. Authors' statements appeared in different types of literary texts: A. Tvardovsky manifested himself mostly in poetry, while

(c) Siberian Federal University. All rights reserved

* Corresponding author E-mail address: onovikova2012@mail.ru 
V. Astafiev wrote the prose. Tvardovsky was published for the first time in 1925, Astafiev in 1951. Despite age difference and existing esthetic distinctions, one cannot fail to notice certain bindings between them, both at genealogic and literary levels.

A. Tvardovsky was born on June 21, 1910 in Smolensk oblast, at a farm near Stolpovo barren assigned to Zagor'e. Having become a famous poet, he preferred trips to his native region to trendy journeys to virgin lands. He called Smolensk oblast "a hard, non-parade and kind of unremarkable area" [Tvardovsky (1976-1983), (6), p. 430].

V. Astafiev was born on May 1, 1924 in the village Ovsianka in Krasnoyarsk Krai. Friends visited the house of the writer and had always admired the beauty of nature in Siberian region. At the sight of village surroundings one of them exclaimed: "Even if one does not want to, he would become a writer anyway!" Deploring the desecrated former beauty, the writer once said: "Ovsianka village is not the same anymore. There are some worker's settlements, plenty of dachas around it. Where in the past there was a faint pathway in the grass which led to the mill and village, now there is a railway and an asphalt highway..." [Astafiev (1994), p. 10]. The theme of "small motherland" and bygone patriarchal way of life is an integral part of the creative world of both writers.

Many worldview foundations of Tvardovsky and Astafiev are based on the real-life experience of peasant life. Thus, both writers created similar characters of a village boy, a "peasant child" defining the peculiarities of temper and nature characteristic. In 1954 the poem "Mne pamiatno kak umiral moi ded..." [I remember how my grandfather died...] by Tvardovsky was published, where he described the situation of waiting and getting the most desired treat of village boys $-\mathrm{a}$ horse-shaped cake:
Мы с ним дружили. Он любил меня.

Я тосковал, когда он был в отлучке,

И пряничного ждал себе коня,

Что он обычно приносил с получки.

[Tvardovsky, A.T. (1976-1983), (3), p. 66].

In the story "Kon' $\mathrm{s}$ rozovoi grivoi" [A horse with a pink mane] by Astafiev which was published for the first time in 1963, Vitya Potylitsyn was promised the precious cake by his grandmother for gathering berries in the forest: "A horse-shaped cake! That's a dream of all village little kids. The horse is white. And its mane, tail, eyes and hooves are pink" [Astafiev (2003), p. 46].

Deaths of kindred people became bitter losses in the childhood of both authors and their autobiographic characters. Tvardovsky wrote after the decease of his grandfather:

И вот он умер, и в гробу своем,

Накрытом крышкой, унесен куда-то.

И нет его, а мы себе живем, -

То первая была моя утрата...

И словно вдруг за некоей чертой

Осталось детства моего начало.

Я видел смерть, и доля смерти той

Мне на душу мою ребячью пала.

[Tvardovsky, A.T. (1976-1983), (3), p. 66].

Astafiev told about his grievous loss in the chapter called "Poslednii poklon" [The last bow] of the eponymously-named book "Soon grandmother died". But the narrator did not manage to attend the funeral: the chief of railway car shed did not let him go and it remained an open sore: "How could he know that my grandfather was like a mother and a father, she was the dearest person! I should tell him where to go, quit job, sell the last trousers and boots and hurry to my grandmother's funeral and I did not do it. I did not yet realize the immensity of my 
loss. If it happened now, I would crawl from the Urals to Siberia to close my grandmother's eyes and give her the last bow. There is guilt living in my heart. Depressing, silent, eternal. I feel guilty for my grandmother, I am trying to revive her in my memory, find out the details of her life" [Astafiev (2003), p. 626].

There is much in common in the tragic rise of the writers. In 1931, Tvardovsky's family was claimed to be kulak and exiled to the North of the country. Poet's younger brother Ivan Trifonovich clarified: "The reason was that they imposed an individual tax on father's household and the amount was so high that there was no sense in trying to pay it. We should sell everything and even after that we would not manage to pay it off" [Tvardovsky (1996), p. 626]. A freight train with carriages overcrowded with special settlers stopped at the station Lialia. Here right in the forest the arrivals had to build barracks to live in for the winter. The poet, who left Zagor'e before the exile of his family always was on the verge of the same fate. In the poem "Brat'ia" [Brothers] (1933) he asked:

Что ж ты, брат?

Как ты, брат?

Где ты, брат?

На каком Беломорском канале?

[Tvardovsky, A.T. (1976-1983), (1), p. 69].

By the example of tragic destiny of his family, in the autobiographic novel "Pan Tvardovsky" he wanted to show the tragedy of Russian peasantry of the $20^{\text {th }}$ century, but this epic concept remained unrealized.

V. Astafiev in his autobiographic narration "The last bow" described the tragedy of his childhood. In 1931, his father and grandfather were arrested "for the establishment of counter-revolutionary armed organization in Ovsianka”. The prison term in a camp for his grandfather was changed to a five-year exile in Igarka, where the whole family was exiled, and his father was sent to the construction of the White Sea-Baltic Sea Canal. In 1931, one more tragedy happened in the family: the mother sank in the Yenisei. The orphaned boy found himself in his grandparents' house. Having returned after the confinement his father tried to take him to a new family. But the relations with the step-mother went wrong and the child remained alone. He studied carelessly, bummed, roamed and was finally sent to Igarka orphan home. There the teachers found a living spark in the soul of a restless, sensitive boy with a bad temper, noticed his interest in books and began fostering interest in creative writing.

Russian village with its unchangeable values left an indelible imprint in the memory of A. Tvardovsky and V. Astafiev. The writers always looked at everything through the lens of peasant psychology and all their works are suffused with worry about the destiny of the Russian world.

Having observed typological analogies, let us address the issue of literary connections between the writers. In 1985 Astafiev came to Smolensk. Here he visited teacher's institute where A. Tvardovsky had studied for two years, thoroughly examined his "Educational record" which was miraculously spared in the archive of Smolensk State University, visited Zagor'e farm and other memorial places connected with the poet. Waiting for the transport for a trip to the "small motherland" of A. Tvardovsky, the honorary guest from Siberia took a long walk with new acquaintances in an autumn park in the center of the city. During the walk and after it at the festive table Astafiev talked about himself and his creative plans, about his idea to write a completely unique book about the war, with all the bitter truth. He was talking about the novel "Prokliaty i ubity" [Cursed and Killed]. At the farewell meeting the writer presented 
Smolensk citizens with the books with memorial inscriptions.

Three years later after the trip to Smolensk oblast, the book "Zriachii posokh" [Seeing Staff] (1988) was published. In this book, he remembered and described in detail his meeting with A.T. Tvardovsky, the chief editor of Novy Mir journal and told about the role that he played in Astafiev's life. "I talked to Aleksandr Trifonovich Tvardovsky in person once and only for fifteen minutes. It was in the late $50 \mathrm{~s}$ or in the early 60s. I was in Moscow. There were three or four of my novels in the editor's office of Novy Mir. I did not foster hopes for a publication, but I was cheered up because they took me and it was not some unknown journal, but Novy Mir with Tvardovsky, who personally! himself! read all! manuscripts submitted to the editor's office" [Astafiev (1988), p. 155]. This is how Astafiev started his story. As he writes further, about meeting Tvardovsky, he "briefly and strongly" shook his hand and "looked closely", showing hospitality, "amiability and wish to do good" in his glance. Having learned that his interlocutor was a soldier at front, the chief editor "discreetly switched the topic to the war", approved the fact that "former soldiers begin to write", contributing "new material" to literature. Astafiev outlined Tvardovsky's clean and ironed shirt, his "large, peasant hands" and "free grey hair" [Astafiev (1988), p. 161-162].

At that time Tvardovsky gave priceless pieces of advice to the unfledged writer. The editor asked: "Why do you mingle author's and narrative speech so carelessly and even deliberately?" According to his own words, Astafiev "was about to blurt" that it was his "peculiarity". Tvardovsky read an example from his text and young Astafiev felt ashamed and brightened up: "thankfully, I did not say anything" [Astafiev (1988), p. 163]. "Then he came across a description of a tree without a top which was broken by a storm.
- A broken but strong tree as a larch that you describe should have many tops! - And he told me that in Pakhra where he lives there is a broken fir and that fir which should have only one top has several branches, one of which will become the top of the tree.

He spoke with me about the story "Burelom" [Windfall] and briefly but very decisively proved that neither storm nor windfall is the main thing in the story but the confrontation of people during a storm, the confrontation of light and dark $<$... $>$.

I listened to Aleksandr Trifonovich and after some years with great difficulty finished that story. It was called "Vos'moi pobeg" [The eighth escape]" [Astafiev (1988), p. 163].

At parting Tvardovsky "cheerly" smiled and said, "You should work a little bit more on the stories and then come to us and publish them - it should be notable and worthy" <..>. And I only repeated: "Thank you! Thank you!" < ...

Aleksandr Trifonovich stood up, shook my hand and, holding it, kind of fenced me with his shoulder and left arm and led to the door" $<\ldots>$.

Unfortunately, Aleksandr Trifonovich deceased and there are different people in the journal working in a different way $<\ldots>$.

And these fifteen minutes which a great poet and citizen of our time spent on me I will work off for the rest of my life" [Astafiev (1988), p. 164166], admits Astafiev. The memoirist finishes his portrait with an artistic comparison: "Nowadays there are many people in our literature who see and remember themselves as a sugar-topped Eastern cake - at once it was round, fluffy, sweet and festive. But there is ascension of bread wheat on the soil, plowed by father and mother. It seems to me that the life and works of Tvardovsky can be compared to this bread wheat in the field of Russian literature..." [Astafiev (1988), p. 161]. (And even earlier, in November 1965 in the letter to A. Makarov, Astafiev compared Tvardovsky to a Russian stove, "which has inner, long-lasting 
warmth and like a good medicine can cure bone diseases and runny nose"; this comparison appeared under the influence of "life in a village" [Astafiev (2009), p. 75].

Thus, the author acknowledged Tvardovsky's lessons. Tvardovsky's daughter kept a book "The last bow" presented by Astafiev with an autograph "which definitely characterize his attitude towards A.T. "To Valentina Aleksandrovna Tvardovskaia with respect and cordial feeling to everything left after Your Great father - worshiping his memory. V. Astafiev. 13 January 1985" [Tvardovskaya (2015)]. Taking into account the recognition of Tvardovsky's talent we can assume the presence of facts of his literary influence on Astafiev's works.

The parallels between the chapter "Pereprava" [Crossing] from the poem "Vasily Terkin" and scenes of crossing the Dnieper in the novel "Cursed and killed" [Rybal'chenko (2007)] which have been already stated by the researchers are quite logic. A tragic episode described in Tvardovsky's poem:

\section{Переправа, переправа! \\ Берег левый, берег правый, \\ Снег шершавый, кромка льда.,}

Кому память, кому слава,

Кому темная вода, -

Ни приметы, ни следа

$<\ldots>$

Густо было там народу -

Наших стриженых ребят...

И увиделось впервые,

Не забудется оно:

Люди теплые, живые

Шли на дно, на дно, на дно..

[Tvardovsky, A.T. (1976-1983),

(2), p. 175, 177], in Astafiev's novel gets a kind of development, obtaining details and naturalistic additions, descriptions of "emerged corpses".

The main character of Astafiev's story "Veselyi soldat" [A Merry Soldier] bears certain similarity to the character of Vasily Terkin [Goncharov (2003)].

The publication of N.V. Kovtun "Motives of home and path in V. Astafiev's story "Pass" [Kovtun (2010)], the title of which is aligned with a famous monograph of A.Makedonov "Tvardovsky's creative career: Houses and paths" (Moscow, 1981) encourages the continuation of the conversation. In 2009, Astafiev's “Epistolary diary" was published and Tvardovsky was mentioned there quite often. The writer has no scruples about using the highest epithets characterizing the chief editor of Novy Mir: "for our times this is a great and almost saint figure", "it is a good thing that he is" [Astafiev (2009), p. 77], etc.

In one of the letters written in 1925, Astafiev called the name of the poet among persons "who had been trying to tell the truth about the war and because of it died early..." [Astafiev (2009), p. 564]. Following the same way, Astafiev acts as a rigorous realist and does not spare esthetic feelings of readers; he deliberately fills his texts with "death material". For comparison, let us remember the lines of the chapter "Rodina i chuzhbina" [Motherland and outland] by Tvardovsky, where the author describes logged bridging with sympathy towards ruined trees that were "beaten, worn out with tank and carrier tracks, wheels" [Tvardovsky, A.T. (1976-1983), (4), p. 252]. In Astafiev's memory the road was made of other "material": "I saw our soldiers on Zhitomir roadway, so rutted in wet mud that they were not thicker than plywood, and their heads were so flattened that they resembled washbasins. I have never seen greater outrage of a man towards another man. We retreated from Zhitomir, our 
vehicles, tanks and attacking German machinery drove over people; conducting an attack in January we again drove over those densely layered corpses in our vehicles and tanks" [Astafiev (2009), p. 232].

Astafiev was attracted by the possibilities of flash fiction, "pocket-book format", which are fulfilled in "Motherland and outland", the book created out of Tvardovsky's "scattered" sketches and notebooks from the wartime. Following T. Mann, he often said that "the whole consists of small parts", and noted that "such "unnecessary" notes, "sketches" as writers call them, often allow rendering more summed up and expressive thoughts in comparison to certain "obligatory" works complied with strict genre rules" [Tvardovsky, A.T. (1976-1983), (6), p. 437]. The poet used the word "bits" as a synonym [Tvardovsky, A.T. (1976-1983), (6), p. 417]. Notebooks were like an "escape" for Tvardovsky as they were not only his "creative laboratory" but also gave him an opportunity to speak sincerely with himself and imagined readers. Astafiev's "Zatesi" [Notches] are of the same nature, i.e. "outside genre"; he has the same understanding of book appearance reasons, created "as if "only for himself": "This image of fictional prose is created due to all the fuss of our life and the absence of an interlocutor. A way to lessen the burden. It substitutes diaries, pocketbooks as I do not have any. It has turned out that such an intimate soliloquy is what readers really need." [Astafiev (1989)]. It should be noted that starting from 1982 "Notches" have been published structurally divided into "notebooks".

"When A.Tverdovsky was interested in him, he invited him to the journal" [Tvardovskaya (2015)], states V.A. Tvardovskaya. The poet did not left any evidence of it in his notes "I do not remember any talks about Astafiev. However, I did not ask about him" [Tvardovskaya (2015)], adds Valentina Aleksandrovna. But of course Astafiev was willing to publish his works in the best Russian journal of the 60s, Novy Mir, diaries of deputy chief editors A. Kondratovich and V. Lakshin contain sufficient confirmations of it. But the editorial staff did not manage to gain the right to publish Astafiev's novel "Krazha" [Theft] from the censors. After that the writer took it back and easily published it in Sibirskie ogni journal. Only in 1967 Astafiev's story "Solnechnym li dnem" [On a sunny day], that became "the apotheosis of the 'plain man' theme", appeared in Novy Mir. We should also pay tribute to Tvardovsky, because under his guidance I. Borisova's article "Introduction (about Viktor Astafiev's works)" appeared in the section "Literary criticism" (1970, No. 1), and was acknowledged as "prominent" providing a deep analysis of writer's earlier works, observed evolutionary.

In summary, it should be noted that our observations are only initial approaches to the solution of the stated problem. Astafiev for sure realized Tvardovsky's importance in his own development as a writer. Apparently, together with a more detailed observation of the stated theme, a number of examples confirming this statement will also increase. (Even today in popular mentality there is an idea of Astafiev being a "student" of Tvardovsky [9].

Such ideas inevitably lead to the main conclusion: having learned Tvardovsky's creative lessons, Astafiev managed to develop his literary skills in an individual manner and gained his rightful place in the history of Russian literature. 


\section{References}

Answers@mail.ru. [Electronic resource]. Available at: http//otvet.mail.ru/question/75231133

Astafiev, V.P. (1988). Zriachii posokh [A seeing staff]. Kniga prozy [Prose book]. Moscow, Sovremennik, $590 \mathrm{p}$.

Astafiev, V.P. (2009). Net mne otveta...[There is no answer for me...]. Epistoliarnyi dnevnik 19522001 [Epistolary diary 1952-2001]. Irkutsk, Izdatel' Sapronov, 720 p.

Astafiev, V.P. (1994). Prokliaty i ubity [Cursed and killed]. Moscow, Veche, 169 p.

Astafiev, V.P. (1989). Solzhenitsyn. Doroga domoi [Solzhenitsyn. Trip home]. In Komsomol'skaia Pravda, October 25, 4.

Astafiev, V.P. (2003). Poslednii poklon [The last bow]. Ekaterinburg, U-Faktoria, 720 p.

Goncharov, P.A. (2003). Raboty V.P. Astaf'eva v kontekste russkoi prozy 1950-1990kh [V.P. Astafiev's works in the context of Russian prose 1950 - 1990s]. Moscow, Vysshaia shkola, 386 p.

Kovtun, N.V. (2009). Derevenskaia proza v zerkale utopii [Village prose in the utopia mirror]. Monograph. Novosibirsk, the Siberian Branch of the Russian Academy of Science, $434 \mathrm{p}$.

Kovtun, N.V. (2010). Motivy doma i puti v rasskaze V. Astaf'eva 'Pereval"' [Motives of home and path in V. Astafiev's story "Pass"]. In Ural'skaia literature: istoriia i sovremennost' [Ural Literature: history and modernity]. (5), Ekaterinburg, 258-271.

Russkie pisateli 20 veka. Bibliograficheskii slovar' [Russian writers of the $20^{\text {th }}$ century. Biographical dictionary] (2000). Bolshaia Sovetskaia Entsiklopediia [Great Soviet Encyclopedia]. Chief editor P.A. Nikolaev. Moscow, Randevu-AM, 808 p.

Rybal'chenko, T.L. (2007). Motiv pogruzheniia v vodu v proze V.P. Astaf'eva [The motif of submersion into water in the prose of V.P. Astafiev]. IV Astaf'evskie chteniia v Krasnoiarske: natsional'noe i regional'noe v russkom iazuke i literature. 12-13 sentiabria 2006 g. [IV Astafiev's Readings in Krasnoyarsk: national and regional in the Russian language and literature. September 1213, 2006.]. Krasnoyarsk, KSPU, 44-61.

Tvardovskaya, V.A. (2015). Pis'mo O.A. Novikovoi ot 14 oktiabria 2015 [O.A. Novikova's letter dated 14 October 2015]. Lichnyi arkhiv O.A. Novikovoi [Personal archive of O.A. Novikova].

Tvardovsky, A.T. (1976-1983). Sobranie sochinenii v 6 tomakh [Collection of works in 6 volumes]. Moscow, Khudozhestvennaia literatura.

Tvardovsky, I.T. (1996). Rodina i chuzhbina [Motherland and outland]. Smolensk, Posokh, $352 \mathrm{p}$. 


\title{
А.Т. Твардовский \\ в творческом сознании В.П. Астафьева
}

\author{
В.В. Ильин, О.А. Новикова \\ Смоленский государственный университет \\ Россия, 214000, Смоленск, ул. Пржевальского, 4
}

B cтатье рассматривается отношение B. Астафьева $к$ личности и творчеству A.Твардовского. Мемуарные записи Астафьева демонстрируют его почтительное отношение к Твардовскому-поэту и Твардовскому - редактору журнала «Новый мир». Сравнительный анализ произведений двух крупных русских писателей-традиционалистов выявляет некоторые типологические аналогии, литературные связи и литературные влияния. Привлечены материаль сочинений авторов, научные работы по теме исследования, отзывы литературной критики. Использованы ранее не публиковавииеся биографические факть Астафьева, связаннье с поездкой писателя в Смоленскую область (1985), свидетельства дочери Твардовского. Установлено наличие параллелей и возможных заимствований в системе образов и мотивов писателей.

Ключевые слова: В. Астафьев, А. Твардовский, писатели-традиционалисты, компаративистика, психология творчества, литературная традиция, журнал «Новый мир».

Научная специальность: 10.00.00 - филологические науки. 